\title{
MEMBANGUN KESEHATAN MENTAL SELAMA PANDEMI COVID-19 DENGAN KREATIVITAS SISWA PONDOK PESANTREN TAHFIDZ QURAN MASSAROTUL, KOTA SERANG
}

\author{
Linardita Ferial \\ Universitas Banten Jaya, Jl Syech Nawawi Albantani Serang, Banten, Indonesia \\ Email: linarditaferial@unbaja.ac.id
}

\begin{abstract}
The COVID-19 pandemic that has hit the whole world and Indonesia has had a huge impact, especially in the field of education, where many students have decreased their mental health due to lack of activity so that this community service aims to reduce student stress levels in an effort to build mental health with creativity in during the COVID-19 pandemic, which is located at the Massarotul Muhtajin Tahfidz Qur'an Islamic Boarding School, Serang City with the target of this community service is students or female students. Community service uses a workshop approach using lectures, discussions and exercises with making souvenirs with 60 participants. In carrying out community service, there are several processes in its implementation including the preparation of the materials used by preparing the main ingredients from shells, training the service team before training participants, implementing training and evaluating training activities. The use of shellfish as a basic material for making souvenirs aims to reuse shellfish waste so as to increase the aesthetic value and economic selling value of shellfish waste. The results of the dedication of this activity show that the number of participants who are enthusiastic about the activity, as many as $80 \%$ of the participants already understand and can be creative in making souvenirs so that they can reduce stress levels and this training can foster a spirit of creativity in the participants in an effort to improve mental health. Each participant has a creativity that grows a new product that has useful value, such as making souvenirs in the form of brooches and flower arrangements so that there needs to be an effort in the future for the boarding school and the government to carry out similar activities regularly to monitor health status regularly in connection with mental health during the COVID-19 pandemic.
\end{abstract}

Keywords: Mental Health; COVID-19; Creativity.

\begin{abstract}
ABSTRAK
Pandemi COVID-19 yang telah melanda seluruh dunia maupun Indonesia memberikan dampak yang sangat besar khususnya di bidang pendidikan, dimana banyaknya siswa yang menurun kesehatan mentalnya karena kurangnya aktivitas sehingga dilakukan pengabdian masyarakat ini bertujuan untuk mengurangi tingkat stress siswa dalam upaya membangun kesehatan mental dengan kreativitas di masa pandemi COVID-19 yang berlokasikan di Pondok Pesantren Tahfidz Qur'an Massarotul Muhtajin, Kota Serang dengan sasaran dalam pengabdian masyarakat ini adalah peserta didik atau siswi-siswi. Pengabdian pada masyarakat menggunakan pendekatan workshop dengan menggunakan metode ceramah, diskusi dan latihan dengan pembuatan cendramata dengan peserta 60 orang. Dalam melakukan pengabdian masyarakat terdapat beberapa proses dalam pelaksanaannya meliputi persiapan bahan yang digunakan dengan mempersiapkan bahan-bahan dengan bahan utama dari cangkang kerang, pelatihan tim pengabdian sebelum dilakukannya pelatihan kepada peserta, pelaksanaan pelatihan dan evaluasi dari kegiatan pelatihan. Penggunaan kerang sebagai bahan dasar pembuatan cendramata ini bertujuan untuk memanfaatkan kembali limbah cangkang kerang sehingga dapat meningkatkan nilai estetika dan nilai jual ekonomis dari limbah cangkang kerang. Hasil pengabdian dari kegiatan ini menunjukkan bahwa banyaknya peserta yang antusias terhadap kegiatan, sebanyak $80 \%$ peserta sudah memahami dan dapat berkreasi dalam pembuatan cendramata sehingga dapat menurunkan tingkat kestressan dan pelatihan ini dapat menumbuhkan jiwa kreativitas di peserta dalam upaya meningkatkan kesehatan mental. Adanya suatu kreatifitas yang dimiliki oleh setiap peserta menumbuhkan suatu produk terbaru yang memiliki nilai guna seperti pembuatan cendramata berupa bros dan rangkaian bunga sehingga perlu adanya suatu upaya kedepannya untuk pihak
\end{abstract}


pondok pesantren dan pemerintah supaya melakukan kegiatan serupa secara rutin guna pemantauan derajat kesehatan secara berkala berkaitan dengan kesehatan mental di masa pandemi COVID-19.

Kata kunci: Kesehatan Mental; COVID-19; Kreativitas.

\section{PENDAHULUAN}

Pandemi Coronavirus (COVID-19) yang masih berlangsung saat ini banyak memberikan dampak negatif pada banyak sektor kehidupan masyarakat di seluruh dunia. Diantaranya sektor kesehatan, pangan, manufaktur, pariwisata dan termasuk pendidikan. Pandemi ini sangat memberikan dampak kepanikan diseluruh dunia (Rahman \& Bahar, 2020). Isolasi, pembatasan kebijakan seperti larangan perjalanan ke dalam dan ke luar, penutupan industri baik badan bisnis swasta maupun internasional, pusat perbelanjaan, museum, bioskop, hotel, kolam renang, tempat ibadah, tempat-tempat pertemuan besar, termasuk semua lembaga pendidikan dan penutupan ekonomi memaksakan perubahan total pada lingkungan psikososial di negara-negara yang terkena dampak. Langkah-langkah ini berpotensi mengancam kesehatan mental anak-anak dan remaja secara signifikan terkait dengan berbagai efek fisik, seperti penurunan aktivitas motorik, perubahan dalam kebiasaan makan, dan tidak ada paparan sinar matahari, bersamaan dengan efek psikologis yang merugikan, seperti tingkat kestresan, ketakutan, kecemasan, dan depresi. Rasa kecemasan yang timbul dikalangan remaja dan anak-anak akibat kurangnya kontak dengan teman sebaya dan berkurangnya peluang untuk pengaturan stress, dimana hal ini menjadi masalah utama yang menimbulkan potensi terjadinya gangguan mental di kalangan remaja dan anak-anak (Mahmudah et al., 2020).

Salah satu dampak besar yang sangat dirasakan karena adanya suatu perubahan dalam masyarakat di kalangan remaja pada sektor pendidikan utamanya pelaksanaan proses belajar mengajar. Berbagai survei penelitian telah dilakukan untuk mengukur tingkat kesehatan mental pada pelajar didunia, survei yang dilakukan Faisal (2021) menemukan bahwa mahasiswa di Bangladesh mengalami kecemasan tingkat tinggi, gejala depresi, dan status kesehatan mental yang rendah saat menghadapi berbagai perubahan akibat virus COVID-19 pada April 2020. Penelitian di Tiongkok juga menemukan bahwa akibat COVID-19, sebanyak 24,9\% mahasiswa mengalami kecemasan yang tinggi selama proses belajar (Wenjun et al., 2020). Di Indonesia, Studi yang dilakukan di Universitas Mulawarman juga menemukan sebanyak 16,5\% mahasiswa dilaporkan mengalami gejala depresi sedang hingga berat; 28,8\% mengalami gejala kecemasan sedang hingga berat, dan 8,1\% mengalami tingkat stres sedang hingga kritis (Fadillah, 2013).

Pada awal April lalu, pemerintah Indonesia menetapkan kebijakan yang tegas melalui aturan pembatasan sosial berskala besar untuk menekan penyebaran COVID-19. Langkah progresif diambil untuk membatasi penyebaran virus melalui pembatasan gerak masyarakat. Di bidang pendidikan, pembelajaran dari rumah menjadi satu-satunya solusi supaya sistem 
pembelajaran tetap berjalan. Pembelajaran dari rumah dilaksanakan secara online atau biasa disebut $e$-learning atau daring, dan melalui Televisi Republik Indonesia (TVRI) yang menyiarkan siaran pendidikan secara serentak, setiap hari, di setiap jenjang Pendidikan (Fadillah, 2013). Pembelajaran daring dianggap kurang menyenangkan dan memiliki banyak kendala dalam pelaksanaannya karena faktor kurangnya fasilitas yang memadai secara individual serta kesiapan baik dari guru, siswa maupun orang tua yang masih rendah. Hasil survei Komisi Perlindungan anak (KPAI) menyebutkan bahwa siswa sebagai respondennya banyak mengeluhkan berbagai kendala, diantaranya waktu pengerjaan tugas yang sempit sehingga membuat siswa kurang istirahat dan kelelahan, masih banyak mahasiswa tidak memiliki fasilitas yang memadai seperti laptop atau handphone dengan spesifikasi memadai untuk belajar daring, interaksi belajar mengajar seperti pada ruang kelas sudah hilang, tidak ada interaksi belajar seperti tanya jawab dan penjelasan materi dari guru.

Proses pembelajaran daring yang dilakukan secara terus menerus diekspektasikan dapat menurunkan kesehatan mental siswa. Berbagai gejala penurunan kesehatan mental siswa diketahui dari banyaknya siswa yang mengalami kecemasan tingkat tinggi, memiliki rasa khawatir yang berlebihan. Selain itu, kebanyakan siswa juga diketahui merasa tertekan akibat banyaknya tugas-tugas yang diberikan oleh guru yang juga menyebabkan mereka kekurangan waktu untuk beristirahat (Mahmudah et al., 2020). Pandemi COVID-19 sampai saat ini belum ditemukan ujung penyelesaiannya, cluster baru terus bermunculan yang semakin menimbulkan keresahan di masyarakat, sehingga memaksa kebijakan pemerintah terus berjalan, artinya pelaksanaan proses belajar mengajar akan tetap mengandalkan sistem pembelajaran dari rumah saja sampai kondisi dinilai lebih stabil dan aman. Hal ini juga sangat berpengaruh terhadap kesehatan mental peserta didik di Pondok Pesantren Tahfidz Qur'an Massarotul Muhtajin sehingga sebagai akademisi, tim pengabdian sangat prihatin dengan keadaan ini. Sebagai bentuk keprihatinan sosial, tim pengabdian berupaya mengadakan beberapa kegiatan Pengabdian kepada Masyarakat $(\mathrm{PkM})$ dalam bentuk membangun kesehatan mental dengan pengembangan kreativitas siswa di Pondok Pesantren Tahfidz Qur'an Massarotul Muhtajin, Kota Serang akibat adanya wabah COVID-19. Adapun kegiatan ini bertujuan untuk mengurangi tingkat stress siswa dalam upaya membangun kesehatan mental dengan kreativitas di masa pandemi COVID-19.

\section{METODE}

Sasaran pengabdian masyarakat ini merupakan semua siswa di Pondok Pesantren, dimana pelaksanaan pengabdian ini tentu saja melibatkan beberapa pihak baik dari ketua pengurus pondok pesantren maupun ketua kelas dari setiap kelas untuk mengkoordinasikan peserta didik lainnya. Permasalahan yang dihadapi peserta didik di masa pandemi dengan meningkatnya rasa 
stress yang berkaitan dengan kesehatan mental maka LP3M Universitas Banten Jaya beserta dosen-dosen mengadakan suatu kegiatan sosialisasi dalam menumbuhkan kreativitas siswa.

Pelaksanaan pengabdian dilakukan dengan tiga tahapan, dimana untuk tahapan pertama dilakukannya tahap persiapan. Pada tahap ini tim pengabdian melakukan suatu survey pendahuluan untuk melihat kondisi di lapangan. Tahapan selanjutnya merupakan tahapan pelaksanaan kegiatan pengabdian. Dalam tahap ini tim pengabdi melakukan kegiatan peragaan dalam pembuatan kerajinan tangan dari bahan kerang, pemilihan bahan dasar kerang ini dikarenakan keberadaan kerang ini mudah ditemukan di daerah tersebut sehingga untuk kedepannya bisa dilakukannya pemanfaatan kembali limbah yang berasal dari kerang tersebut. Tahapan terakhir yaitu dilakukannya tahap evaluasi. Pada tahap ini dilakukan evaluasi atas hasil yang telah dicapai oleh peserta didik dengan memaparkan secara langsung hasil karya yang telah dibuat.

Indikator ketercapaian tujuan dari pengabdian ini diharapkan bahwa $80 \%$ peserta didik atau siswa sudah memahami dan dapat berkreasi dalam pembuatan cendramata sehingga dapat menurunkan tingkat kestressan di masa pandemi. Pendekatan kegiatan pengabdian pada masyarakat ini dikemas dengan menggunakan pendekatan workshop. Dimana kegiatan ini dilakukan menggunakan metode ceramah, diskusi dan latihan dengan pembuatan cendramata atau hasil kerajinan tangan yang memiliki nilai produktivitas sehingga dari kegiatan ini dapat meningkatkan kreativitas di kalangan peserta didik atau siswa. Kegiatan pengabdian kepada masyarakat ini dilakukan pada tanggal 17 November 2020 berlokasi di Pondok Pesantren Tahfidz Qur'an Massarotul Muhtajin, Kota Serang. Sasaran pengabdian masyarakat ini adalah siswasiswa Pondok Pesantren Tahfidz Qur’an Massarotul Muhtajin, Kota Serang.

\section{HASIL DAN PEMBAHASAN}

Pondok Pesantren Tahfidz Qur'an Massarotul Muhtajin terletak di jalan Syaikh Muhammad Al-Khidhir, Banten, Kecamatan Kasemen, Desa Sukadiri, Kota Serang, Banten. Dimana Kecamatan Kasemen berjarak 9 km ke Ibukota Serang, 16 km ke Ibukota Provinsi Banten dan $\pm 73 \mathrm{~km}$ ke Kota Jakarta, Ibukota Negara Indonesia. Lokasi pondok pesantren ini berhadapan langsung dengan Kesultanan Banten, dengan lokasi pesantren yang sangat strategis menjadi daya tarik untuk siswa mengemban ilmu di Pondok Pesantren Tahfidz Qur'an Massarotul Muhtajin. Peserta didik atau lebih sering disebut dengan santri di Pondok Pesantren Tahfidz Qur'an Massarotul Muhtajin, Kota Serang, Banten ini terdiri atas santri putra dan putri dengan pemisahan bangunan antara santri putra dibagian depan dan santri putri dibagian belakang dan pemilihan partisipan untuk dilakukannya pelatihan pada santri putri karena erat kaitannya dengan kegiatan pembuatan cendramata. Pemilihan lokasi pengabdian ini berlandaskan pada peningkatan 
kreativitas penduduk di daerah Kasemen khususnya penduduk dalam usia muda.

Kecamatan Kasemen dikenal dengan daerah pesisir. Hal ini dikarenakan letak kelurahannya dekat dengan pesisir pantai dan mayoritas warganya memang berprofesi sebagai nelayan. Berbagai macam hasil tangkapan laut yang diperoleh para nelayan salah satunya adalah kerang. Keberadaan kerang sangat melimpah. Namun kerang yang dihasilkan hanya dimanfaatkan bagian dagingnya saja, sedangkan untuk cangkang kerang hanya menjadi limbah yang tidak dapat diurai oleh tanah. Alternatif yang dilakukan yaitu memanfaatkan limbah cangkang kerang yang diolah menjadi kerajinan tangan seperti bros supaya dapat meningkatkan perekonomian warga Kasemen yang memiliki nilai estetika dan nilai jual ekonomis serta dapat meningkatkan kreativitas santri sehingga dapat mengurangi tingkat ke stressan siswa di masa pandemi. Tidak hanya kerang saja yang menjadi bahan dasar dalam pembuatan cendramata atau kerajinan tangan ini tetapi juga terdapat bahan-bahan lainnya seperti kain flannel, lem tembak, dan pin yang dapat dilihat pada Gambar 1 .

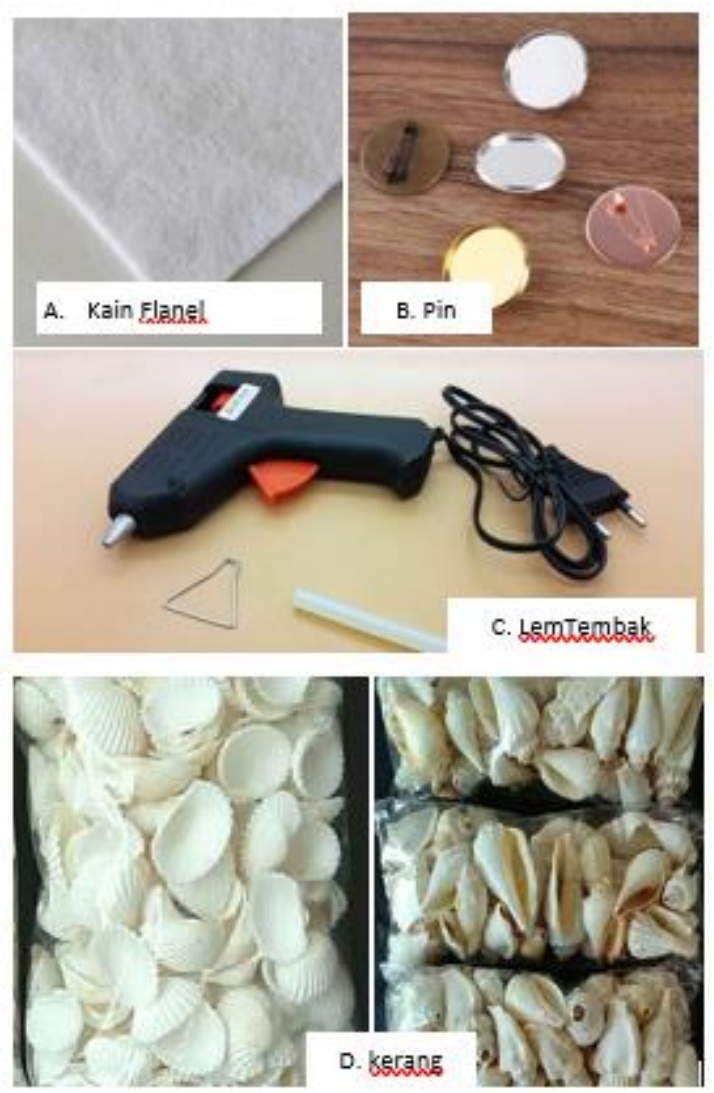

Gambar 1. Bahan-Bahan Pembuatan Cendramata

Dari bahan-bahan yang telah dipersiapkan dilakukan prosedur pembuatan kerajinan tangan dari kerang, dimana kain flannel dilakukan membentukan pola lingkaran yang sesuai dengan bentuk pin yang digunakan setelah kain flannel berbentuk lingkaran selanjutnya dilakukan 
pengeleman antara kain flannel dengan pin menggunakan lem tembak untuk tempat kerang dibuatkan pola tergantung dengan kreativitas masing-masing siswa.

Sebelum dilakukannya pelatihan kepada peserta didik terlebih dahulu melakukan simulasi pelatihan yang dilaksanakan di Universitas Banten Jaya perlunya kegiatan simulasi ini untuk melatih tim pelatihan terlebih dahulu sebelum dilakukan pelatihan kepada peserta didik dan kegiatan pelatihan dapat berjalan dengan lancar tanpa ada hambatan. Tidak hanya dilakukannya pelatihan saja tetapi tim juga mempersiapkan bahan-bahan yang akan digunakan pada saat workshop di Pondok Pesantren Tahfidz Qur'an Massarotul Muhtajin. Adapun proses persiapan dan pelatihan tim pengabdian dalam mempersiapkan kegiatan pelatihan pembuatan kerajinan tangan atau cenderamata berbahan dasar kerang ini diikuti oleh semua dosen yang melakukan pengabdian

Pelatihan pembuatan cendramata dari bahan kerang ini diikuti dengan antusias oleh siswisiswi Pondok Pesantren Tahfidz Qur'an Massarotul Muhtajin. Pelaksanaan pelatihan dilakukan pada pukul 09.00 WIB di aula Pondok Pesantren Tahfidz Qur'an Massarotul Muhtajin setelah para peserta didik melakukan pembelajaran di kelas masing-masing sehingga kegiatan pelatihan pembuatan kerajinanan tangan atau cendramata ini tidak mengganggu proses pembelajaran di pondok pesantren tersebut. Sebelum dilakukan pelatihan terlebih dahulu tim pelatih mengambil bahan-bahan yang telah dipersiapkan untuk dilakukan peragaan kepada peserta didik, selanjutnya dilakukan suatu pembagian kelompok menjadi enam bagian dengan masing-masing 10 anggota dan 3 pelatih dalam satu kelompok. Setelah dilakukan pembagian kelompok, terlebih dahulu pelatih melakukan peragaan cara-cara pembuatan cendramata dan peserta didik menyimak dengan seksama sehingga nantinya peserta didik dapat membuat secara mandi. Dimana proses peragaan dari tim pelatih dapat dilihat pada Gambar 2.



Gambar 2. Peragaan Pembuatan Cendramata Berbahan Kerang 
Setelah dilakukan peragaan oleh tim pelatih selanjutnya peserta didik atau santri wati dibagikan bahan-bahan untuk mencobanya secara mandiri dengan didampingi oleh tim pelatih dan peserta didik juga diberikan kebebasan dalam pembuatan bros sehingga dapat menumbuhkan rasa kreativitas dalam kegiatan ini. Kebebasan dalam pembuatan bros ini menciptakan hasil cendramata yang berbeda-beda antara satu peserta dengan peserta yang lainnya. Dimana kegiatan para peserta didik mencoba mengembangkan kreativitasnya ini dapat dilihat pada Gambar 3.

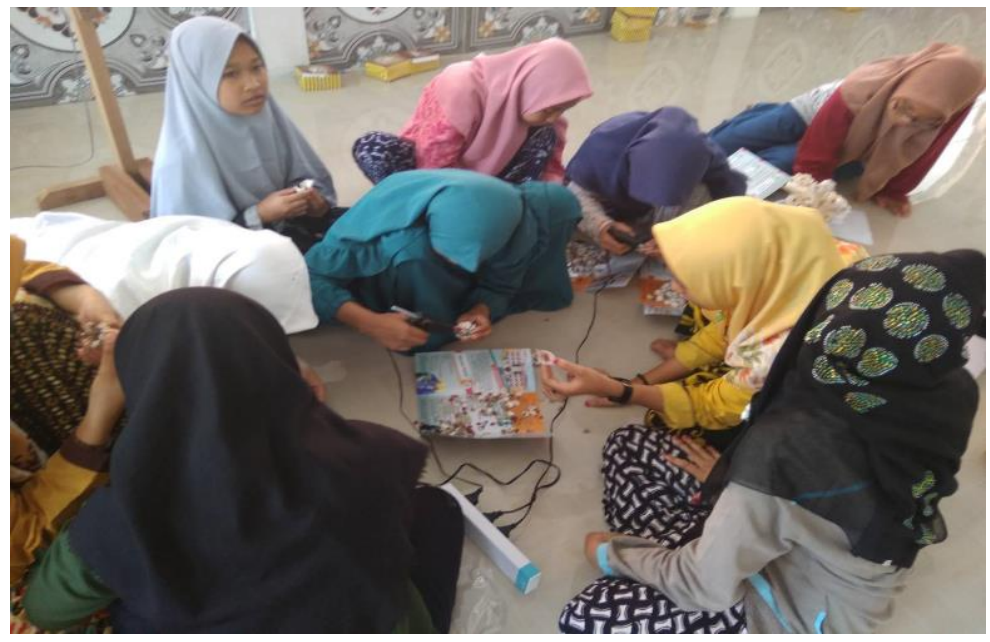

Gambar 3. Proses Pembuatan Cendramata oleh Peserta Didik

Dalam kegiatan ini terdapat keterbatasan alat yaitu lem tembak karena harga lem tembak sendiri yang cukup mahal jika diadakan peralat untuk satu peserta didik, sehingga adanya keterbatasan alat ini peserta didik melakukan antrian lem tembak, karena lem tembak ini menggunakan listrik dan cairan lem yang dikeluarkan dari alat tersebut bersifat panas jika terpegang oleh tangan maka perlu adanya pengawasan dari tim pelatihan kepada setiap peserta didik yang akan mencoba. Penggunaan lem tembak disini bertujuan untuk mempercepat proses pembuatan kerajinanan tangan dan hasil yang didapatkan akan rapih dan bagus tetapi jika peserta didik dikemudian hari ingin mencoba kembali untuk pembuatan bros tidak menggunakan lem tembak melainkan menggunakan lem biasa bisa menjadi alternative tetapi membutuhkan waktu untuk lem tersebut kering antara kain flannel dengan kerang.

Peserta didik yang telah menunggu giliran lem tembak melakukan perancangan pola bros sehingga setelah salah satu peserta didik telah selesai menggunakan lem tembak bisa dilakukan perekatan antara kerang yang telah di susun menggunakan lem tembak tersebut. Dengan suatu kreativitas yang dimiliki setiap peserta didik berbeda-beda menghasilkan suatu kerajinan yang beragam sehingga kerajinan tangan yang dibuat oleh setiap peserta didik akan berbeda-beda tergantung dengan kreativitas yang dimiliki oleh setiap peserta didik. Pola pengasahan kreativitas ini juga memberikan dampak positif kepada proses pembelajaran peserta didik kedepannya 
sehingga diharapkan dengan pengasahan kreativitas ini menunjang nilai akademik maupun non akademik serta dari pola pengasahan kreativitas membuat peserta didik lebih aktiv dalam melakukan suatu kegiatan guna membangun kesehatan mental peserta didik dikemudian hari. Bentuk kreativitas yang diciptakan oleh peserta didik tidak hanya dilakukan pembuatan bros saja, ada beberapa peserta didik yang mencoba melakukan pembuatan bunga dari bahan kerang dengan membuat beberapa bentuk bunga yang dilakukan pengrangkaian atau disusun sehingga berbentuk rangkaian bunga yang memiliki nilai estetik yang dapat dilihat pada Gambar 4.



Gambar 4. Kreativitas Peserta Didik

Proses pelatihan pembuatan kerajinan tangan ini berlangsung selama 3 jam dimana setiap perpeserta membutuhkan waktu selama 10 menit mulai dari perancangan pola kerang yang akan disusun sampai ke proses finnising untuk pembuatan cendramata bros sedangkan untuk peserta yang mencoba membuat bunga membutuhkan waktu lebih lama yaitu antara 30 menit sampai 40 menit. Dengan kegiatan ini banyak peserta didik atau santri wati yang merasa bangga akan apa yang telah mereka buat yang merupakan hasil dari kreativitas sendiri.

Penumbuhan rasa bangga akan hasil yang peserta didik atau santri wati buat ini akan berdampak kepada rasa percaya diri peserta didik dalam menghasilkan sesuatu yang baru dan akan meningkatkan kesehatan mental dari masing-masing peserta didik. Dengan adanya kegiatan pembuatan cendramata ini mendorong setiap peserta untuk mengisi waktu luang atau waktu istirahat mereka menciptakan suatu karya yang dapat mereka gunakan dikemudian hari atau bahwa hasil karya yang mereka ciptakan bisa menjadi nilai ekonomis yang menumbuhkan skill atau kemampuan tambahan dari pengembangan kreativitas yang dimiliki.

Pada tahapan evaluasi semua hasil karya peserta didik dikumpulkan untuk dilihat oleh tim pelatih masing-masing kelompok untuk dilihat dan diberikan suatu apresiasi dari hasil karya yang telah mereka buat. sebanyak $80 \%$ peserta didik atau siswa sudah memahami dan dapat 
berkreasi dalam pembuatan cendramata sehingga dapat menurunkan tingkat kestressan di masa pandemi. Dengan tingginya kreativitas yang dimiliki oleh peserta didik atau siswa akan menumbuhkan suatu kegiatan positif dalam mengisi waktu luang sehingga dengan adanya kegiatan ini, proses pembuatan kerajinan tangan dapat menciptakan suatu produk yang memiliki nilai estetik dan nilai guna dari limbah yaitu cangkang kerang. Adapun hasil karya yang telah dibuat peserta didik dapat dilihat pada Gambar 5.

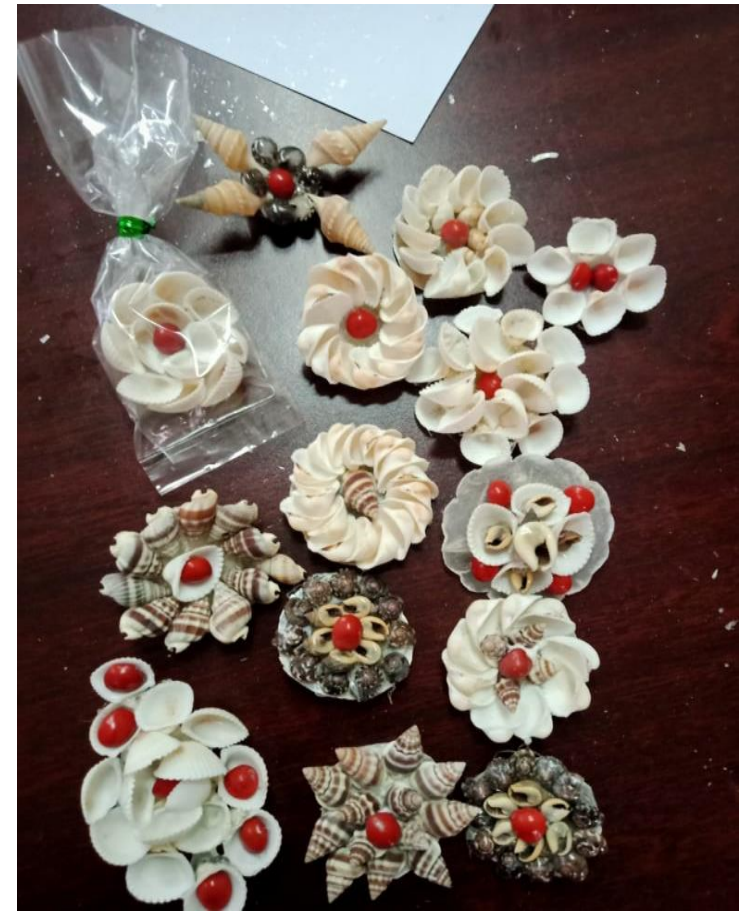

\section{Gambar 5. Hasil Karya Peserta}

Dengan adanya suatu apresiasi yang diberikan kepada peserta didik akan menimbulkan rasa senang dan bangga dari hasil karyanya sehingga rasa senang dan bangga tersebut akan timbul efek kepada kesehatan mental dari setiap peserta didik serta timbul keinginan untuk terus membuat kerajinan tangan atau cendramata dari bahan kerang dengan pola yang berbeda sehingga dengan adanya kegiatan positif yang dilakukan peserta didik atau santri wati dalam menunggu kelas atau mengisi waktu istirahatnya seperti membuat kreasi yang bermanfaat dan dapat mengurangi rasa stress di masa pandemi akibat kejenuhan dalam mengisi waktu.

Dari kegiatan pelatihan ini juga tidak hanya memberikan efek pada kesehatan mental dari peserta didik tetapi juga memiliki nilai tambah tinggi, yaitu pemanfaatan berbagai limbah seperti limbah dari hasil laut berupa kerang-kerangan. Proses pemanfaatan kembali limbah cangkang kerang ini berguna untuk mengurangi limbah ada di lingkungan dan pemanfaatan ini merupakan bagian dari terselenggaranya program daur ulang limbah. Cangkang-cangkang kerang yang biasa ditemukan di pantai dan tindak memiliki nilai guna dapat dibuat menjadi kerajinan tangan yang 
beraneka ragam bentuk, sesuai kreativitas masing-masing tergantung dengan keinginan dari masing-masing peserta. Setelah semua rangkaian pelatihan selesai dilakukan maka dilakukannya dokumentasi antara tim pelatih dengan peserta didik yang dapat dilihat pada gambar 6 .

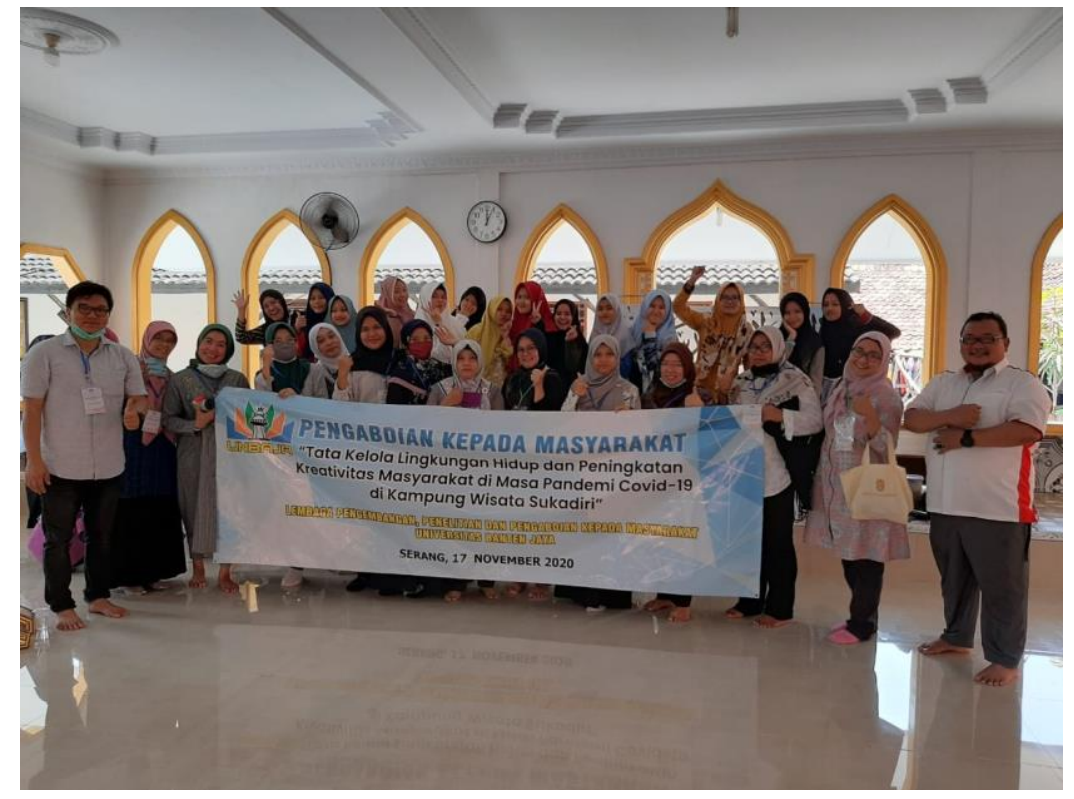

Gambar 6. Dokumentasi Tim Pelatih dengan Peserta Didik

Sikap antusias dari para peserta didik menjadi kunci keberhasilan dari pelaksanaan pengabdian masyarakat di Pondok Pesantren Tahfidz Qur'an Massarotul Muhtajin dibuktikan dengan banyaknya peserta yang mengikuti dari awal hingga pelatihan ini selesai.

\section{KESIMPULAN}

Workshop atau pelatihan tentang menumbuhkan jiwa kreativitas di peserta didik dalam upaya meningkatkan kesehatan mental dapat memberikan wawasan baru bagi siswa dalam meningkatkan kreativitas dengan pemanfaat kembali limbah seperti kerang. Dimana indikator ketercapaian dari pengabdian ini sekitar $80 \%$ peserta didik atau siswa sudah memahami dan dapat berkreasi dalam pembuatan cendramata sehingga dapat menurunkan tingkat kestressan di masa pandemi. Saran untuk pihak pondok pesantren dan pemerintah supaya melakukan kegiatan serupa secara rutin dan pemantauan derajat kesehatan secara berkala.

\section{UCAPAN TERIMA KASIH}

Kami mengucapkan terima kasih kepada Pondok Pesantren Tahfidz Qur'an Massarotul Muhtajin, Kota Serang telah memberikan izin dan membantu dalam pelaksanaan pengabdian masyarakat. 


\section{DAFTAR PUSTAKA}

Fadillah, A. (2013). Stress dan Motivasi Belajar Pada mahasiswa Psikologi Universitas Mulawarman yang Sedang Menyusun Skripsi. EJournal Psikologi, 1, 254-267.

Faisal, R. A., Jobe, M. C., Ahmed, O., \& Sharker, T. (2021). Mental Health Status, Anxiety, and Depression Levels of Bangladeshi University Students During the COVID-19 Pandemic. International Journal of Mental Health and Addiction. https://doi.org/10.1007/s11469-02000458-y

Mahmudah, U., Chamdani, M., Tarmidzi, T., \& Fatimah, S. (2020). Robust regression for estimating the impact of student's social behaviors on scientific literacy. Cakrawala Pendidikan, 39(2), 293-304. https://doi.org/10.21831/cp.v39i2.29842

Rahman, S., \& Bahar, T. (2020). COVID-19: The New Threat. International Journal of Infection, 7(1), 1-6. https://doi.org/10.5812/iji.102184

Wenjun, C., Ziwei, F., Guoqiang, H., Mei, H., Xinrong, X., Jiaxin, D., \& Jianzhong, Z. (2020). The psychological impact of the COVID-19 epidemic on college students in China. $\begin{array}{llll}\text { Psychiatry } & \text { Research, } & \text { 287(March } & \text { 20, }\end{array}$ http://www.embase.com/search/results?subaction=viewrecord\&from=export\&id=L200540 6993\%0Ahttp://dx.doi.org/10.1016/j.psychres.2020.112934 